\title{
Implikasi Hukum Terhadap Akta Yang Dibuat Oleh Notaris Yang Tidak Dibacakan Dan Ditandatangani Secara Bersama-Sama
}

\author{
Mia Elvina \\ Fakultas HukumUniversitas Islam Indonesia Yogyakarta Indonesia \\ Jln. Cik Di Tiro No. 1, Yogyakarta, Indonesia 55223 \\ miaelvina20@yahoo.com
}

\begin{abstract}
The purpose of this research is to examine the reality that happens in the practice of notaries that often occurs and unavoidable, namely where the applicants do not come before the notary at the same time. This is common almost every region. Not only violating the principle of propriety, it is also a sporadic habit that is considered a trivial matter. This is a juridical-empirical legal research on the implementation of normative legal provisions in real behavior that occurs in society. The results of the study conclude that the lack of awareness of the Notary in practicing and implementing authentic deed-making procedures based on the provisions of the Law and the weak supervision of the institutions that are obliged to supervise Notaries in carrying out their duties and functions, making the Notary who is a bank partner does not read out and ensure that the deed is signed properly together. Furthermore, the reading and signing of the deed that was not carried out in front of a notary would result in a decrease in the authenticity value of the deed into an under-hand deed.
\end{abstract}

Key Words: Deed-making procedures; notary; notary supervision

\begin{abstract}
Abstrak
Tujuan dari penelitian ini adalah mengkaji realita yang terjadi dalam praktek Notaris yang sering terjadi dan tidak dapat dihindari, yakni dimana para penghadap tidak menghadap Notaris pada saat yang bersamaan. Hampir di setiap daerah, hal tersebut lumrah dilakukan. Bukan hanya melanggar asas kepatutan, hal tersebut juga merupakan kebiasaan yang menjamur namun dianggap hal yang sepele. Penelitian hukum ini bersifat yuridis-empiris, mengenai pemberlakuan atau implementasi dari ketentuan hukum normatif secara perilaku nyata yang terjadi di masyarakat. Hasil penelitian menyimpulkan kurangnya kesadaran Notaris dalam mengamalkan dan melaksanakan prosedur pembuatan akta otentik berdasarkan ketentuan Undang-Undang maupun lemahnya pengawasan dari lembaga-lembaga yang berkewajiban untuk mengawasi Notaris dalam menjalankan tugas dan jabatannya, menjadikan Notaris yang menjadi rekanan bank tidak membacakan dan memastikan akta ditandatangani secara bersama-sama. Kemudian hasil penelitian berikutnya merumuskan bahwa pembacaan dan penandatanganan akta yang tidak dilakukan di hadapan Notaris akan berakibat turunnya nilai pembuktian akta otentik menjadi akta di bawah tangan.
\end{abstract}

Kata-kata Kunci: Notaris; prosedur pembuatan akta; pengawasan notaris 


\section{Pendahuluan}

Negara Republik Indonesia sebagai negara hukum berdasarkan Pancasila dan Undang-Undang Dasar Negara Republik Indonesia Tahun 1945 menjamin kepastian, ketertiban, dan perlindungan hukum bagi setiap warga negara. Untuk menjamin kepastian, ketertiban, dan perlindungan hukum dibutuhkan alat bukti tertulis yang bersifat otentik mengenai perbuatan, perjanjian, penetapan, dan peristiwa hukum yang dibuat di hadapan atau oleh pejabat yang berwenang. ${ }^{1}$

Notaris merupakan suatu jabatan di bidang hukum yang terkait erat dengan pembuatan alat bukti berupa akta. 1860 Pemerintah Hindia Belanda memandang perlu untuk membuat peraturan-peraturan yang mengatur mengenai jabatan Notaris di Nederlands Indie untuk disesuaikan dengan peraturan-peraturan mengenai jabatan Notaris yang berlaku di Belanda. Keberadaannya di nusantara sejak zaman kolonial Belanda mendasarkan pada Reglement op Het Notaris Ambt in Indonesie (Stb. 1860 No.3). ${ }^{2}$

Peraturan kolonial Belanda ini berlangsung hingga masa kemerdekaan Indonesia yaitu dengan diundangkannya Undang-Undang Nomor 30 Tahun 2004 tentang Jabatan Notaris. ${ }^{3}$ Semenjak Indonesia merdeka, lembaga Notariat terus digunakan oleh masyarakat dan menjadi lembaga hukum Indonesia, dimanfaatkan oleh semua golongan. Bagi mereka yang tunduk kepada hukum adat tidak lagi harus menyatakan tunduk kepada hukum Eropa, bahkan perjanjiannya sendiri yang dituangkan ke dalam akta boleh merupakan materi yang diatur dalam hukum adat dan hukum Islam. ${ }^{4}$

Notaris berdasarkan ketentuan Pasal 1 angka 1 Undang-Undang Nomor 2 Tahun 2014 tentang Perubahan Atas Undang-Undang Nomor 30 Tahun 2004 tentang Jabatan Notaris menyebutkan bahwa, "Notaris adalah pejabat umum yang berwenang untuk membuat akta otentik dan memiliki kewenangan lainnya sebagaimana dimaksud dalam Undang-Undang ini atau berdasarkan undangundang lainnya."Sehingga dapat dipahami bahwa Notaris adalah pejabat umum yang secara khusus diberikan wewenang oleh undang-undang untuk membuat suatu alat bukti yang otentik (mempunyai kekuatan pembuktian yang sempurna).

${ }^{1}$ Muhammad Luthfan Hadi Darus, Hukum Notariat dan Tanggung Jawab Jabatan Notaris, Cetakan Pertama UII Press, Yogyakarta, 2017, hlm. 1.

${ }^{2}$ Stb. 1860 No. 3 diundangkan untuk menggantikan aturan sebelumnya, yakni Stb. No. 11.

${ }^{3}$ Abdul Ghofur Anshori, Lembaga Kenotariatan Indonesia; Perspektif Hukum dan Etika, Cetakan Pertama, UII Press, Yogyakarta, 2009, hlm. 101.

${ }^{4}$ R. Soegondo Notosoedirjo, Hukum Notariat di Indonesia; Suatu Penjelasan, PT. RajaGrafindo Persada, Jakarta, 1993, hlm. 4. 
Rumusan atas unsur-unsur Notaris sebagaimana yang terdapat dalam Undang-Undang Nomor 2 Tahun 2014 tentang Perubahan Atas Undang-Undang Nomor 30 Tahun 2004 tentang Jabatan Notaris terdiri dari:

1. Pejabat umum;

2. Mempunyai kewenangan untuk membuat akta otentik;

3. Kewenangan lainnya yang diberikan oleh undang-undang di luar UndangUndang Jabatan Notaris.

4. Setiap wewenang yang diberikan kepada jabatan harus ada aturan hukumnya. Sebagai batasan agar jabatan dapat berjalan dengan baik, dan tidak bertabrakan dengan wewenang jabatan lainnya. Dengan demikian jika seseorang pejabat Notaris melakukan suatu tindakan yang bukan wewenangnya sebagaimana telah ditentukan, dapat dikategorikan sebagai perbuatan melanggar wewenang. Wewenang Notaris dicantumkan dalam Pasal 15 ayat (1), (2), dan (3) Undang-Undang Jabatan Notaris:

(1)Notaris berwenang membuat Akta autentik mengenai semua perbuatan, perjanjian, dan penetapan yang diharuskan oleh peraturan perundangundangan dan/atau yang dikehendaki oleh yang berkepentingan untuk dinyatakan dalam Akta autentik, menjamin kepastian tanggal pembuatan Akta, menyimpan Akta, memberikan grosse, salinan dan kutipan Akta, semuanya itu sepanjang pembuatan Akta itu tidak juga ditugaskan atau dikecualikan kepada pejabat lain atau orang lain yang ditetapkan oleh undang-undang.

(2)Selain kewenangan sebagaimana dimaksud pada ayat (1), Notaris berwenang pula:

a. mengesahkan tanda tangan dan menetapkan kepastian tanggal surat di bawah tangan dengan mendaftar dalam buku khusus;

b. membukukan surat di bawah tangan dengan mendaftar dalam buku khusus;

c. membuat kopi dari asli surat di bawah tangan berupa salinan yang memuat uraian sebagaimana ditulis dan digambarkan dalam surat yang bersangkutan;

d. melakukan pengesahan kecocokan fotokopi dengan surat aslinya;

e. memberikan penyuluhan hukum sehubungan dengan pembuatan akta;

f. membuat akta yang berkaitan dengan pertanahan; ataug. membuat akta risalah lelang.

(3 Selain kewenangan sebagaimana dimaksud pada ayat (1) dan ayat (2), Notaris mempunyai kewenangan lain yang diatur dalam peraturan perundang-undangan."

Sebagai penegasan tentang kewenangan Notaris dalam pembuatan akta otentik yang diatur di luar Undang-Undang Jabatan Notaris sebagaimana yang terdapat dalam Pasal 1868 KUHPerdata tersebut dinyatakan bahwa, "akta otentik ialah suatu akta yang yang di dalam bentuk yang ditentukan oleh undang- 
undang dibuat oleh atau di hadapan pejabat umum yang berwenang di tempat dimana akta itu dibuat."

Prosedur pembuatan akta otentik mengacu pada ketentuan Undang-Undang Nomor 2 Tahun 2014 tentang Perubahan Atas Undang-Undang Nomor 30 Tahun 2004 tentang Jabatan Notaris, mengenai bentuk dan fungsi akta Notaris secara khusus telah diatur di dalam Pasal 38, selanjutnya mengenai bentuk dan sifat akta tersebut dirumuskan sebagai berikut:

(1)Setiap Akta terdiri atas:

a. awal Akta atau kepala Akta;

b. badan Akta; dan

c. akhir atau penutup Akta.

(2)Awal Akta atau kepala Akta memuat:

a. judul Akta;

b. nomor Akta;

c. jam, hari, tanggal, bulan, dan tahun; dan

d. nama lengkap dan tempat kedudukan Notaris.

(3) Badan Akta memuat:

a. nama lengkap, tempat dan tanggal lahir, kewarganegaraan, pekerjaan, jabatan, kedudukan, tempat tinggal para penghadap dan/atau orang yang mereka wakili;

b. keterangan mengenai kedudukan bertindak penghadap;

c. isi Akta yang merupakan kehendak dan keinginan dari pihak yang berkepentingan; dan

d. nama lengkap, tempat dan tanggal lahir, serta pekerjaan, jabatan, kedudukan, dan tempat tinggal dari tiap-tiap saksi pengenal.

(4) Akhir atau penutup Akta memuat:

a. uraian tentang pembacaan Akta sebagaimana dimaksud dalam Pasal 16 ayat (1) huruf $m$ atau Pasal 16 ayat (7);

b. uraian tentang penandatanganan dan tempat penandatanganan atau penerjemahan Akta jika ada;

c. nama lengkap, tempat dan tanggal lahir, pekerjaan, jabatan, kedudukan, dan tempat tinggal dari tiap-tiap saksi Akta; dan

d. uraian tentang tidak adanya perubahan yang terjadi dalam pembuatan Akta atau uraian tentang adanya perubahan yang dapat berupa penambahan, pencoretan, atau penggantian serta jumlah perubahannya.

(5)Akta Notaris Pengganti dan Pejabat Sementara Notaris, selain memuat ketentuan sebagaimana dimaksud pada ayat (2), ayat (3), dan ayat (4), juga memuat nomor dan tanggal penetapan pengangkatan, serta pejabat yang mengangkatnya."

Ketentuan dalam Pasal 38 UUJN ini merupakan syarat-syarat yang harus dipenuhi sebagai akta Notaris (akta otentik). Apabila dihubungkan dengan ketentuan Pasal 1868 KUHPerdata Jo Pasal 1869 KUHPerdata yang merupakan 
sumber otentisitas akta Notaris dan juga sebagai legalitas eksistensi akta Notaris. Akta otentik sebagai alat bukti terkuat dan terpenuh mempunyai peranan penting dalam setiap hubungan hukum dalam kehidupan masyarakat. Dalam berbagai hubungan bisnis, kegiatan di bidang perbankan, pertanahan, kegiatan sosial, dan lain-lain. Kebutuhan akan pembuktian tertulis berupa akta otentik makin meningkat sejalan dengan berkembangnya tuntutan akan kepastian hukum dalam berbagai hubungan ekonomi dan sosial, baik dalam tingkat nasional, regional, maupun global.

Melalui akta otentik yang menentukan secara jelas hak dan kewajiban, menjamin kepastian hukum, dan sekaligus diharapkan pula dapat dihindari terjadinya sengketa. Walaupun sengketa tersebut dapat dihindari, dalam proses penyelesaian sengketa tersebut, akta otentik yang merupakan alat bukti tertulis dan terpenuh memberi sumbangan nyata bagi penyelesaian perkara secara murah dan cepat.Jabatan Notaris diadakan atau kehadirannya dikehendaki oleh aturan hukum dengan maksud untuk membantu dan melayani masyarakat yang membutuhkan alat bukti tertulis yang bersifat otentik mengenai keadaan, peristiwa, atau perbuatan hukum. ${ }^{5}$ Dengan dasar seperti ini mereka yang diangkat sebagai Notaris harus mempunyai semangat untuk melayani masyarakat, dan atas pelayanan tersebut, masyarakat yang telah merasa dilayani oleh Notaris sesuai dengan tugas jabatannya, dapat memberikan honorarium kepada Notaris. ${ }^{6}$ Oleh karena itu Notaris tidak berarti apa-apa jika masyarakat tidak membutuhkannya. Pernyataan tersebut hubungan masyarakat dengan Notaris adalah layanan jasa produk hukum.

Notaris wajib berpedoman secara normatif kepada aturan hukum yang berkaitan dengan segala tindakan yang akan diambil untuk kemudian dituangkan ke dalam akta. Bertindak berdasarkan aturan hukum yang berlaku akan memberikan kepastian kepada para pihak, bahwa akta yang dibuat di hadapan atau oleh Notaris telah sesuai dengan aturan hukum yang berlaku, sehingga jika terjadi permasalahan, akta Notaris dapat dijadikan pedoman oleh para pihak.

Dalam konstruksi hukum kenotariatan, bahwa salah satu tugas jabatan Notaris yaitu memformulasikan keinginan/tindakan penghadap/para penghadap ke dalam bentuk akta otentik, dengan tetap memperhatikan aturan

${ }^{5}$ Habib Adjie, Hukum Notaris Indonesia; Tafsir Tematik Terbadap Undang-Undang Nomor 30 Tabun 2004 Tentang Jabatan Notaris, Cetakan Keempat, Refika Aditama, Bandung, 2014, hlm. 14.

${ }^{6}$ Mengenai Honorarium ini dicantumkan dalam Pasal 36 UUJN. Pencantuman Honorarium dalam UUJN tidak punya daya paksa untuk Notaris dan untuk para pihak yang membutuhkan jasa Notaris, dan juga tidak ada yang mengawasi jika Notaris mengikuti atau tidak mengikuti ketentuan tersebut, dan dalam keadaan tertentu Notaris wajib untuk tidak meminta atau menerima honorarium. 
hukum yang berlaku, tidak serta merta menuangkan ke dalam akta seluruh kehendak penghadap. Karena Notaris yang lalai atau bertindak di luar wewenangnya dapat dijatuhi sanksi, baik berupa sanksi pidana, sanksi perdata, maupun sanksi administratif, oleh sebab itu Notaris juga dituntut untuk mampu bersikap profesional dalam menjalankan tugas.

Notaris dalam menjalankan tugas kewenangannya sebagai pejabat umum, mempunyai ciri utama yaitu pada kedudukannya (posisinya) yang tidak memihak dan mandiri bahkan lebih tegas dapat dikatakan "bukan sebagai salah satu pihak", lain halnya dengan eksekutif atau pemerintah atau pejabat tata usaha negara atau pejabat administratif negara. Mereka pada saat menjalankan jabatan dan juga fungsi serta kekuasaannya, jelas sebagai salah satu pihak.Adapun kewajiban Notaris dalam menjalankan tugas jabatannya ialah sebagai berikut:

a. bertindak amanah, jujur, saksama, mandiri, tidak berpihak, dan menjaga kepentingan pihak yang terkait dalam perbuatan hukum;

b. membuat Akta dalam bentuk Minuta Akta dan menyimpannya sebagai bagian dari Protokol Notaris;

c. melekatkan surat dan dokumen serta sidik jari penghadap pada Minuta Akta;

d. mengeluarkan Grosse Akta, Salinan Akta, atau Kutipan Akta berdasarkan Minuta Akta.

e. memberikan pelayanan sesuai dengan ketentuan dalam Undang-Undang ini, kecuali ada alasan untuk menolaknya;

f. merahasiakan segala sesuatu mengenai Akta yang dibuatnya dan segala keterangan yang diperoleh guna pembuatan Akta sesuai dengan sumpah/janji jabatan, kecuali undang-undang menentukan lain;

g. menjilid Akta yang dibuatnya dalam 1 (satu) bulan menjadi buku yang memuat tidak lebih dari 50 (lima puluh) Akta, dan jika jumlah Akta tidak dapat dimuat dalam satu buku, Akta tersebut dapat dijilid menjadi lebih dari satu buku, dan mencatat jumlah Minuta Akta, bulan, dan tahun pembuatannya pada sampul setiap buku;

h. membuat daftar dari Akta protes terhadap tidak dibayar atau tidak diterimanya surat berharga;

i. membuat daftar Akta yang berkenaan dengan wasiat menurut urutan waktu pembuatan Akta setiap bulan;

j. mengirimkan daftar Akta sebagaimana dimaksud dalam huruf i atau daftar nihil yang berkenaan dengan wasiat ke pusat daftar wasiat pada kementerian yang menyelenggarakan urusan pemerintahan di bidang hukum dalam waktu 5 (lima) hari pada minggu pertama setiap bulan berikutnya;

k. mencatat dalam repertorium tanggal pengiriman daftar wasiat pada setiap akhir bulan; 
1. mempunyai cap atau stempel yang memuat lambang negara Republik Indonesia dan pada ruang yang melingkarinya dituliskan nama, jabatan, dan tempat kedudukan yang bersangkutan;

m.membacakan Akta di hadapan penghadap dengan dihadiri oleh paling sedikit 2 (dua) orang saksi, atau 4 (empat) orang saksi khusus untuk pembuatan Akta wasiat di bawah tangan, dan ditandatangani pada saat itu juga oleh penghadap, saksi, dan Notaris;

n. menerima magang calon Notaris.

Sebagai pejabat umum, Notaris harus independen. Istilah independen ini sering diartikan atau disamakan dengan pengertian mandiri. Pada konsep manajemen, penerapan istilah mandiri berarti institusi yang bersangkutan secara manajerial dapat berdiri sendiri tanpa tergantung kepada atasannya, tetapi secara institusional tetap tergantung kepada (depend on) atasannya, sedangkan independen baik secara manajerial maupun institusional tidak tergantung kepada atasannya ataupun pihak lainnya. ${ }^{7}$

Dalam hal ini alasan pentingnya Notaris dalam menciptakan kepatutan tidak terlepas dari kenyataan bahwa tidak semua pihak antara satu dengan lainnya dalam melakukan hubungan hukum utuk membuat perjanjian memiliki keseimbangan kedudukan.Hal ini tidak terlepas dari pengetahuan masyarakat yang masih cenderung rendah dalam memahami hukum-hukum perjanjian yang dibuatnya.Notaris yang diberikan hak dan kewenangan oleh undang-undang untuk membuat akta para pihak, diharapkan dapat menjadi arbitrase atas kepentingan dari pihak agar membuat perjanjian yang selaras dengan prinsipprinsip hukum. Kenyataan ini menjadi alasan penting bagaimana Notaris melakukan reduksi terhadap prinsip kebebasan berkontrak. ${ }^{8}$

Kebutuhan akan jasa Notaris dalam masyarakat modern tidak mungkin dihindarkan. Notaris sebagai pejabat umum diangkat oleh pemerintah dan pemerintah sebagai organ negara mengangkat Notaris bukan semata untuk kepentingan Notaris itu sendiri, melainkan juga untuk kepentingan masyarakat luas. Peran dan keberadaan Notaris juga tidak dapat dapat terhindarkan terhadap praktik perjanjian bisnis perbankan, khususnya dalam pelaksanaan pemberian fasilitas kredit perbankan.

Pinjam-meminjam uang dalam kegiatan perbankan di Indonesia disebut kredit. Salah satu kegiatan usaha yang pokok bagi bank konvensional adalah berupa pemberian kredit dan dikenal dengan sebutan kredit perbankan. Kredit perbankan disalurkan bank kepada masyarakat sesuai dengan fungsi utamanya

${ }^{7}$ Habib Adjie, Hukum Notaris... Op. Cit., hlm. 31. hlm. 58.

${ }^{8}$ Herry Susanto, Peran Notaris Dalam Menciptakan Kepatutan Dalam Kontrak, UII Press, Yogyakarta, 2010, 
menghimpun dan menyalurkan dana masyarakat. Pada proses pelaksanaan pemberian kredit perbankan tersebut biasanya dikaitkan dengan berbagai persyaratan, antara lain mengenai jumlah maksimal kredit, jangka waktu kredit, tujuan penggunaan kredit, suku bunga kredit, cara penarikan dana kredit, jadwal pelunasan kredit, dan jaminan kredit. ${ }^{9}$

Pengertian bank berdasarkan ketentuan Pasal 1 angka 2 Undang-Undang Nomor 10 Tahun 1998 tentang Perbankan adalah badan usaha yang menghimpun dana dari masyarakat dalam bentuk simpanan dan menyalurkannya kepada masyarakat dalam bentuk kredit dan atau bentuk-bentuk lainnya dalam rangka meningkatkan taraf hidup rakyat banyak. Salah satu produk dari bank adalah kredit yang dituangkan dalam bentuk perjanjian kredit. Perjanjian kredit yang dituangkan dalam bentuk akta otentik membutuhkan peran Notaris dalam proses pembuatannya.

Namun terkadang di dalam praktiknya, Notaris yang menjadi rekanan dari pihak perbankan diperhadapkan pada situasi yang harus dilaksanakan, namun pada hakikatnya itu merupakan suatu pelanggaran atau ketidakpatutan sikap dari seorang Notaris. Dalam hal ini integritas seorang Notaris diuji, sampai sejauh mana Notaris tersebut dapat mengamalkan sumpah jabatan yang pernah diucapkan dan spirit menegakkan kode etik seorang Notaris.

Kewajiban Notaris untuk membacakan akta dihadapan penghadap dengan dihadiri oleh paling sedikit 2 (dua) orang saksi dan ditandatangani pada saat itu juga oleh penghadap, saksi, dan Notaris diatur dalam Ketentuan Pasal 16 ayat (1) huruf 1 UUJN. Ketentuan ini dipertegas kembali dalam Pasal 44 UUJN yang menyatakan bahwa segera setelah akta dibacakan, akta tersebut ditandatangani oleh setiap penghadap, saksi, dan Notaris, kecuali apabila ada penghadap yang tidak dapat membubuhkan tanda tangan dengan menyebutkan alasannya. Ketentuan pembacaan dan penandatanganan tersebut adalah satu kesatuan dari peresmian akta (verlijden).

Kemudian, kata di hadapan dalam penandatanganan akta tersebut adalah hadirnya seorang Notaris dalam proses peresmian akta (verlidjen) atau face to face sebagaimana diatur dalam penjelasan Pasal 16 ayat (1) huruf m UUJN. Dalam praktik penandatanganan akta di mana dalam penandatanganannya tidak dilakukan di hadapan para pihak dan saksi-saksi ketika pembuatan akta pembebanan tersebut terjadi secara bersamaan pada tempat yang berbeda. Tidak mungkin berada dalam 2 tempat yang berbeda dalam waktu yang bersamaan.

${ }^{9}$ M. Bahsan, Hukum Jamninan dan Jaminan Kredit Perbankan Indonesia, RajaGrafindo Persada, Jakarta, 2007, 
Merupakan realitas dalam praktek Notaris yang tidak dapat dipungkiri lagi sering (mungkin ada juga yang tidak pernah melakukan) terjadi para penghadap tidak menghadap Notaris pada saat yang bersamaan. Hampir di semua kota provinsi ataupun daerah, hal tersebut lumrah dilakukan, bukan hanya asas kepatutan, namun hal tersebut merupakan kebiasaan yang menjamur tapi dianggap hal yang sepele.

Kepala/Pimpinan Cabang atau yang ditunjuk oleh Bank tidak menghadap, tapi akta ditandatangani/dibacakan oleh Notaris di hadapan debitur dan saksisaksi. Kemudian akta yang telah ditandatangani tersebut dikirimkan kepada pihak bank untuk ditandatangani. Sudah tentu alasan tidak datang dan tanda tangan pada waktu yang sama ada dengan berbagai alasan, yang tidak dapat dinormatifkan (dipastikan) satu persatu, tapi hal yang demikian tentu bertentangan dengan ketentuan yang ada.

Dalam ketentuan Pasal 4 ayat (6) kode etik Notaris Ikatan Notaris Indonesia disebutkan bahwa, "Notaris dan orang lain yang memangku dan menjalankan jabatan Notaris dilarang mengirimkan minuta kepada klien untuk ditandatangani." Kemudian, di dalam ketentuan Pasal 16 ayat (1) huruf m UUJN disebutkan bahwa, Notaris wajib membacakan akta di hadapan penghadap dengan dihadiri oleh paling sedikit 2 orang saksi, atau 4 orang saksi khusus untuk pembuatan akta wasiat di bawah tangan, dan ditandatangani pada saat itu juga oleh penghadap, saksi, dan Notaris.

Notaris yang tidak mematuhi atau tidak menjalankan kewajibannya sesuai dengan ketentuan dalam Pasal 16 ayat (1) huruf m UUJN, dalam hal ini adalah Notaris yang tidak membacakan dan menandatangani akta di hadapan para pihak dan saksi-saksi, maka akan terimplikasi timbulnya akibat hukum, yaitu sebagai berikut. Pertama, akibat hukum terhadap Notaris, adalah pemberhentian sementara dari jabatannya sebagai Notaris karena telah melakukan pelanggaran terhadap kewajiban dan larangan jabatan sebagaimana yang tertuang dalam Pasal 9 ayat (1) huruf d UUJN. Kedua, akibat hukum terhadap akta adalah akta tersebut akan kehilangan otentisitasnya atau terdegradasi menjadi akta di bawah tangan sebagaimana tertuang dalam Pasal 16 ayat (8) UUJN. Mengenai ganti rugi diatur dalam Pasal 84 UUJN, di mana ketentuan pasal tersebut menegaskan tindakan pelanggaran yang dilakukan oleh Notaris yang mengakibatkan akta tersebut terdegradasi menjadi akta di bawah tangan atau suatu akta menjadi batal demi hukum dapat menjadi alasan kepada para pihak yang menderita kerugian untuk penggantian biaya, ganti rugi, dan bunga kepada Notaris.Hal yang demikian menjadi perhatian bagi Penulis, sehingga Penulis tertarik untuk mengangkat 
judul "Implikasi Hukum Terhadap Akta Perjanjian yang dibuat oleh Notaris yang Tidak Dibacakan dan Ditandatangani oleh Penghadap Secara Bersama-sama."

\section{Rumusan Masalah}

Berdasarkan uraian latar belakang di atas, maka rumusan masalah penelitian ini adalah: Pertama, apakah Notaris yang tidak membacakan dan menandatangani akta di hadapan klien merupakan pelanggaran kode etik dan Undang-Undang Jabatan Notaris? Kedua, apa akibat hukum terhadap akta Notaris yang tidak dibacakan dan ditandatangani oleh klien secara bersama-sama?

\section{Tujuan Penelitian}

Adapun tujuan yang hendak dicapai melalui penelitian ini adalah sebagai berikut: Pertama, untuk menganalisis Notaris yang tidak membacakan dan menandatangani akta di hadapan klien apakah merupakan pelanggaran kode etik dan Undang-Undang Jabatan Notaris; Kedua, untuk menganalisis akibat hukum terhadap akta Notaris yang tidak dibacakan dan ditandatangani oleh klien secara bersama-sama.

\section{Metode Penelitian}

Penelitian dengan judul “Implikasi Hukum Terhadap Akta Perjanjian yang Dibuat Oleh Notaris yang Tidak Dibacakan dan Ditandatangani oleh Penghadap Secara Bersama-sama" adalah merupakan penelitian yuridis empiris, yaitu penelitian terhadap norma hukum (yuridis) dan implementasi dari norma tersebut (empiris). Konsekuensi penelitian yuridis empiris adalah penyajian norma-norma hukum (bahan hukum) dan data lapangan.Metode pengumpulan data/bahan yang akan digunakan dalam penelitian ini adalah: a. Data primer yaitu data diperoleh dengan cara wawancara secara langsung dengan pihakpihak yang terkait dengan permasalahan yang diteliti, seperti Notaris, Dewan Kehormatan NotarisKota Yogyakarta, Akademisi. b. Data sekunder diperoleh melalui studi kepustakaan, yaitu dengan menggunakan perundang-undangan dan buku-buku yang terkait dengan masalah yang akan diteliti dalam penelitian ini, dan melakukan pengumpulan data melalui perundang-undangan yaitu terkait dengan masalah yang diteliti, dan juga melalui internet, majalah, dan melalui kamus hukum, kamus bahasa, dan kamus lain yang berhubungan dengan permasalahan yang akan diteliti dalam penelitian ini. 


\section{Hasil Penelitian dan Pembahasan}

\section{Analisis Yuridis Terhadap Notaris yang Tidak Membacakan dan Menandatangani Akta di Hadapan Klien}

Seiring dengan perkembangan kehidupan yang semakin modern, yang diwarnai dengan meningkatnya hubungan antara sesama warga negara ataupun lembaga-lembaga pemerintah dan lembaga sosial, maka akan sangat terasa sekali pentingnya jasa pelayanan Notaris terutama dalam hal pembuatan akta otentik. Dengan demikian, jabatan Notaris adalah jabatan mulia dan terhormat karena memberikan pelayanan dan bantuan hukum kepada masyarakat yang mempercayakan pengurusan haknya dalam melakukan perbuatan hukum. Kepercayaan tersebut sudah semestinya dipegang oleh Notaris yang menjalankan tugas jabatannya.

Salah satu produk dari Notaris ialah akta otentik, dimana akta otentik tersebut menjadi kebutuhan bagi masyarakat yang melakukan transaksi-transaksi atau kegiatan-kegiatan keperdataan yang memerlukan suatu alat bukti demi menjaga kepentingan masing-masing pihak yang terlibat. Semakin meningkatnya kesadaran masyarakat akan terpenuhinya suatu alat bukti yang kuat dan sempurna demi menjaga hak-hak mereka di kemudian hari membuat jasa Notaris makin dicari dan dibutuhkan. Namun yang perlu diperhatikan, baik oleh Notaris maupun penghadap atau masyarakat yang menggunakan jasa Notaris ialah prosedur-prosedur yang sudah ditentukan oleh undang-undang dalam pembuatan akta Notaris (akta otentik) agar keotentikan dari akta tersebut dapat terpenuhi.

Dalam praktik pemberian kredit oleh lembaga perbankan kepada nasabah sudah lazim menggunakan jasa Notaris untuk mengikat para pihak dalam suatu akta perjanjian kredit yang dibuat oleh Notaris. Namun berdasarkan hasil pengamatan Penulis, bahwa proses penandatanganan akta perjanjian kredit antara bank dan nasabahnya hanya dihadiri dan ditandatangani oleh nasabah, yang kemudian setelah akta tersebut ditandatangani oleh nasabah maka akta tersebut dikirim kepada pihak bank untuk selanjutnya ditandatangani oleh pihak bank.

Hal yang demikian sudah sering terjadi dan dianggap hal yang benar, padahal apabila kita memperhatikan ketentuan atau prosedur-prosedur pembuatan akta otentik oleh Notaris maka hal yang demikian merupakan suatu pelanggaran aturan hukum yang sudah tentu berimplikasi hukum, baik terhadap akta itu sendiri maupun pihak-pihak yang tersebut di dalam akta itu. Kurangnya kesadaran Notaris dalam mengamalkan dan melaksanakan prosedur pembuatan akta otentik berdasarkan ketentuan undang-undang maupun lemahnya pengawasan dari lembaga-lembaga yang berkewajiban untuk mengawasi Notaris 
dalam menjalankan tugas dan jabatannya menjadikan hal ini terus menerus terjadi.

Sudah menjadi hal yang sering terjadi, dimana proses pembacaan dan penandatanganan akta Notaris tidak dilakukan di hadapan seluruh penghadap, dimana hal tersebut terjadi terhadap Notaris yang menjadi rekanan pihak perbankan. Dalam pengamatan Penulis, bahwa tidak hadirnya pihak dari bank pada saat proses peresmian akta (verlijden) disebabkan karena kesibukan dari pimpinan bank sehingga tidak dapat hadir di hadapan Notaris atau pihak yang berwenang mewakili bank, dalam hal ini biasa dilakukan oleh Head Officer Credit Administration atau pimpinan cabang bank yang bersangkutan dan sudah hal yang dianggap biasa sebab telah dilakukan dari tahun ke tahun. Notaris rekanan bank biasanya hanya mengirimkan kepada pihak bank minuta akta yang telah ditandatangani oleh nasabah dari bank tersebut, yang untuk kemudian akan ditandatangani oleh Head Officer Credit Administration atau pimpinan cabang bank rekanan Notaris. ${ }^{10}$

Sudah sepatutnya akta Notaris memberikan kepastian bahwa suatu kejadian dan fakta tersebut dalam akta betul-betul dilakukan oleh Notaris atau diterangkan oleh pihak-pihak yang menghadap pada saat yang tercantum dalam akta sesuai dengan prosedur yang sudah ditentukan dalam pembuktian akta. Secara formal, untuk membuktikan kebenaran dan kepastian tentang hari, tanggal, bulan, tahun, pukul atau waktu menghadap, dan identitas dari para pihak yang menghadap (comaparanten), paraf dan tanda tangan para pihak/penghadap, membuktikan apa yang dilihat, disaksikan, didengar oleh Notaris pada akta pejabat/berita acara dan mencatatkan keterangan atau pernyataan.

Kewajiban Notaris untuk membacakan akta di hadapan penghadap dengan dihadiri oleh paling sedikit 2 orang saksi dan ditandatangani pada saat itu juga oleh penghadap, saksi, dan Notaris diatur dalam ketentuan Pasal 16 ayat (1) huruf $\mathrm{m}$ Undang-Undang Jabatan Notaris (UUJN) yang menyebutkan, dalam menjalankan jabatannya Notaris wajib membacakan akta di hadapan penghadap dengan dihadiri paling sedikit 2 orang saksi, atau 4 orang saksi khusus untuk pembuatan akta wasiat di bawah tangan dan ditandatangani saat itu juga oleh penghadap, saksi, dan Notaris.

Ketentuan ini dipertegas kembali dalam Pasal 44 UUJN, yang menyatakan bahwa segera setelah akta dibacakan, akta tersebut ditandatangani oleh setiap penghadap, saksi, dan Notaris, kecuali apabila ada penghadap yang tidak dapat

${ }^{10}$ Hasil wawancara dengan Risa Triati, Head Officer Credit Administration Bank Sinar Mas Kota Surabaya, Tanggal 30 April 2020. 
membubuhkan tanda tangan dengan menyebutkan alasannya. Ketentuan pembacaan dan penandatanganan tersebut adalah satu kesatuan dari peresmian akta (verlijden). Kemudian, kata di hadapan dalam penandatanganan akta tersebut adalah hadirnya seorang Notaris dalam proses peresmian akta (verlijden) atau face to face sebagaimana diatur dalam penjelasan Pasal 16 ayat (1) huruf m UUJN.

Dalam praktik penandatanganan akta di mana dalam penandatanganannya tidak dilakukan di hadapan para pihak dan saksi-saksi ketika pembuatan akta pembebanan tersebut terjadi secara bersamaan pada tempat yang berbeda. Menurut Nurhadi Darussalam, hal yang demikian yakni tidak dibacakan dan ditandatanganinya akta oleh Notaris di hadapan penghadap secara bersama-sama merupakan hal yang sudah lazim terjadi dalam praktik kenotariatan, khususnya terhadap Notaris yang menjadi rekanan bank. Seharusnya hal tersebut tidak terjadi sebab jelas-jelas melanggar ketentuan Undang-Undang Jabatan Notaris dan Kode Etik Ikatan Notaris Indonesia. Dilematis memang sebab Notaris di satu sisi juga berlomba-lomba untuk menjadi rekanan dari bank namun di satu sisi ada ketentuan-ketentuan yang harus dipegang teguh oleh Notaris dalam menjalankan praktik sebagai Notaris. Dalam hal ini Notaris harus dapat menegakkan dan menerapkan spirit pelaksanaan tugas jabatan Notaris yang baik, mempunyai kredibilitas sehingga tidak dikontrol oleh bank-bank rekanan. Juga perlunya sinergisitas antara pengurus Ikatan Notaris Indonesia dengan pihak-pihak dari bank yang menjadi rekanan Notaris agar dapat berjalan beriringan tanpa melakukan pelanggaran aturan. ${ }^{11}$

Sebenarnya jika Notaris yang bersangkutan sadar akan tugas dan kewenangannya serta jabatan yang diemban, sudah seharusnya Notaris menolak untuk mengikuti kehendak dari pihak bank yang meminta minuta akta yang telah dibacakan dan ditandatangani oleh Notaris dan nasabah untuk dikirim ke bank untuk selanjutnya ditandatangani sebab hal tersebut jelas bertentangan terhadap ketentuan UUJN dan kode etik Notaris yang akan berimplikasi hukum bagi Notaris itu sendiri di kemudian hari.

Harus juga disadari bahwa Notaris dan produk aktanya dimaknai sebagai upaya negara untuk menciptakan kepastian dan perlindungan hukum bagi masyarakat. Mengingat dalam wilayah hukum privat, negara menempatkan Notaris sebagai pejabat umum yang berwenang dalam hal pembuatan akta otentik, yaitu salah satunya untuk kepentingan pembuktian/alat bukti. Dengan demikian, Notaris wajib untuk menjaga keluhuran jabatan Notaris, jangan sampai

${ }^{11}$ Hasil wawancara dengan Nurhadi DarussalamS.H., M.Hum., Notaris/PPAT di Kabupaten Sleman, Majelis Pengawas Notaris Provinsi Daerah Istimewa Yogyakarta periode 2010-2019, serta akademisi di Universitas Islam Indonesia dan Universitas Gadjah Mada, Tanggal 29 April 2020. 
hanya karena untuk menjaga kepentingan bisnis agar bisa terus menjadi Notaris bank sampai-sampai membuat Notaris menyampingkan dan melanggar ketentuan perundang-undangan.

Juga terhadap pihak bank dimana pihak dari bank tidak hadir pada saat proses peresmian akta (verlijden), dimana harusnya pihak bank harus konsisten dan patuh terhadap ketentuan pembacaan dan penandatanganan akta di hadapan Notaris bersama dengan nasabah sebab akta tersebut merupakan akta milik bank yang akan memberikan perlindungan dalam menjamin kepastian hukum jika debitor atau nasabah wanprestasi.

\section{Akibat Hukum terhadap Akta Notaris yang Tidak Dibacakan dan Ditandatangani oleh Klien Secara Bersama-sama}

Akta otentik didefinisikan sebagai suatu akta yang dibuat di hadapan pejabat yang berwenang yang mana isinya telah disepakati oleh para pihak yang membuat akta tersebut. Dalam akta otentik dapat ditentukan secara jelas tentang hak dan kewajiban para pihak, menjamin kepastian hukum dan diharapkan pula dapat dihindari dalam terjadinya sengketa. Walaupun sengketa tersebut dapat dihindari dalam proses penyelesaian sengketa, akta otentik yang merupakan alat bukti tertulis dan terpenuh memberi sumbangan nyata bagi penyelesaian perkara secara murah dan cepat. ${ }^{12}$

Seiring dengan berjalannya waktu dengan berbagai permasalahan hukum yang semakin berkembang, maka Notaris sebagai pejabat umum yang menjalankan tugas dalam memberikan jasa hukum kepada masyarakat perlu mendapatkan perlindungan dan jaminan demi tercapainya kepastian hukum. Peraturan yang mengatur tentang jabatan Notaris yaitu Undang-Undang Nomor 30 Tahun 2004 tentang Jabatan Notaris sebagaimana telah diubah dengan Undang-Undang Nomor 2 Tahun 2014 tentang perubahan Undang-Undang Nomor 30 Tahun 2004 tentang Jabatan Notaris, (selanjutnya disebut UndangUndang Jabatan Notaris), telah menjadi payung hukum bagi Notaris dalam menjalankan fungsi jabatannya yaitu dengan memberikan jaminan kepada masyarakat bahwasannya seorang Notaris dalam menjalankan tugas dan jabatannya benar-benar untuk kepentingan masyarakat dan bertanggungjawab terhadap pembuatan akta yang dibuat oleh para pihak di hadapan Notaris.

Dapat dipahami bahwa, melaksanakan ketentuan peraturan perundangundangan yang berlaku, khususnya UUJN merupakan payung hukum bagi Notaris agar tidak terlibat dalam permasalahan hukum di kemudian hari. Notaris

${ }^{12}$ Hartanti Sulihandari dan Nisya Rifiani, Op. Cit., hlm. 13-14. 
wajib berpedoman secara normatif kepada aturan hukum yang berkaitan dengan segala tindakan yang akan diambil untuk kemudian dituangkan ke dalam akta. Bertindak berdasarkan aturan hukum yang berlaku akan memberikan kepastian kepada para pihak, bahwa akta yang dibuat di hadapan atau oleh Notaris telah sesuai dengan aturan hukum yang berlaku, sehingga jika terjadi permasalahan, akta Notaris dapat dijadikan pedoman oleh para pihak. Pada bagian awal akta, Notaris mencantumkan tanggal/waktu pembuatan akta. Pencantuman tanggal/waktu ini sangatlah penting sehubungan dengan kekuatan pembuktian formal yang dimiliki akta Notaris. Kekuatan pembuktian formal artinya akta Notaris memberikan kepastian bahwa suatu kejadian dan fakta yang diterangkan oleh pihak-pihak yang menghadap pada saat yang tercantum dalam akta sesuai dengan prosedur yang ditentukan dalam pembuatan akta. ${ }^{13}$

Dalam praktik, sudah banyak terjadi dimana waktu penandatanganan akta tidak dapat dilakukan dalam waktu yang bersamaan antara para penghadap di hadapan Notaris. Dengan demikian, Notaris tidak dapat menyatakan dalam akta yang bersangkutan menurut sebenarnya, bahwa akta itu segera setelah dibacakan kepada para penghadap, ditandatangani oleh mereka, saksi-saksi dan Notaris. Penandatanganan akta yang tidak bersamaan antara para penghadap di hadapan saksi dan Notaris sering terjadi dalam dunia perbankan yaitu pada waktu penandatangan akta perjanjian kredit. Bank sebagai kreditur dengan fungsi pelayanannya kepada nasabah mempunyai prinsip pelayanan yang cepat, tepat dan efisiensi waktu maupun biaya. Karena alasan efisien waktu, maka terjadi "pembenaran" dalam proses pembacaan dan penandatanganan akta oleh Notaris yang tidak dihadiri oleh pihak dari bank.

Tanda tangan biasanya terletak sebagai bagian akhir akta. Pada aturan dasar atau asas dalam common law Inggris yang diberlakukan terhadap perjanjianperjanjian baku agar klausul-klausul eksemsi (dan klausul-klausul yang memberatkan lainnya) yang dimuat dalam suatu perjanjian tertulis yang ditandatangani oleh para pihak mengikat para pihak yang bersangkutan. Begitu pula tentang kehadiran para pihak, dimana dalam pembacaan serta penandatanganan suatu akta, para penghadap saksi-saksi dan Notaris mempunyai kewajiban untuk hadir dan menandatangani akta tersebut. Dalam ketentuan Pasal 16 ayat (1) huruf m Undang-Undang Jabatan Notaris menyebutkan, "Notaris berkewajiban membacakan akta di hadapan penghadap dengan dihadiri oleh paling sedikit 2 orang saksi dan ditandatangani pada saat itu juga oleh penghadap, saksi, dan Notaris." Keabsahan akta Notaris yang

${ }^{13}$ Habib Adjie, Sanksi Perdata dan Administratif Terbadap Notaris Sebagai Pejabat Publik, Refika Aditama, Bandung, 2009, hlm. 19. 
meliputi bentuk, isi, kewenangan pejabat yang membuat serta pembuatan akta tersebut harus memenuhi syarat-syarat yang telah ditentukan di dalam peraturan perundang-undangan yang berlaku.

Akta Notaris memberikan kepastian bahwa sesuatu kejadian dan fakta tersebut dalam akta betul-betul dilakukan oleh Notaris atau diterangkan oleh pihak-pihak yang yang menghadap pada saat yang tercantum dalam akta sesuai dengan prosedur yang sudah ditentukan dalam pembuatan akta Notaris. Secara formal untuk membuktikan kebenaran dan kepastian tentang hari, tanggal, bulan, tahun, pukul (waktu) menghadap, dan para pihak yang menghdap, paraf dan tanda tangan para pihak/penghadap, saksi dan Notaris (pada akta pejabat/berita acara), dan mencatatkan keterangan atau pernyataan para pihak/penghadap (pada akta pihak).

Notaris wajib menjamin kepastian hari, tanggal, bulan, tahun, dan pukul menghadap yang tercantum atau disebutkan pada bagian awal akta Notaris, sebagai bukti bahwa para pihak menghadap dan menandatangani akta pada hari, tanggal, bulan, tahun, dan pukul yang tersebut dalam akta serta semua prosedur pembuatan akta telah dilakukan sesuai aturan hukum yang berlaku dalam UUJN. Dalam kasus akta Notaris tidak dibacakan dan ditandatangani secara bersamasama oleh penghadap di hadapan Notaris yang dikarenakan salah satu pihak yakni pihak perbankan tidak hadir dan hanya dikirimkan salinan akta untuk kemudian ditandatangani sudah tentu bertentangan dengan ketentuan UUJN dan kode etik Notaris yang sudah tentu akan berimplikasi hukum baik terhadap akta tersebut maupun Notaris yang bersangkutan.

Pembacaan dan penandatanganan akta yang tidak dilakukan di hadapan Notaris akan berakibat turunnya nilai pembuktian akta otentik menjadi akta di bawah tangan sebagaimana tertuang dalam Pasal 16 ayat (9) UUJN dan melanggar ketentuan Pasal 4 ayat (6) Kode Etik Ikatan Notaris Indonesia yang menimbulkan konsekuensi yakni berupa sanksi yang dikenakan terhadap anggota (dalam hal ini Notaris) yang melakukan pelanggaran kode etik, yakni berupa teguran, peringatan; schorsing (pemecatan sementara) dari keanggotaan perkumpulan, onzetting (pemecatan) dari keanggotaan perkumpulan, pemberhentian dengan tidak hormat dari keanggotaan perkumpulan.

Penurunan status kekuatan alat bukti akta Notaris dapat terjadi dalam pembuatannya terjadi pelanggaran terhadap ketentuan persyaratan hukum yang berlaku. Salah satu bentuk pelanggaran tersebut adalah membuat akta-akta yang tidak sesuai dengan fakta. Kemudian, yang sangat sering terjadi dan menjadi perhatian Penulis ialah terkait dengan tidak dibacakannya akta dan 
penandatanganan akta yang tidak dilakukan Notaris di hadapan penghadap (klien) secara bersama-sama.

Akta Notaris sebagai alat bukti, agar dapat mempunyai kekuatan pembuktian yang sempurna jika seluruh ketentuan prosedur atau tata cara pembuatan akta tersebut dipenuhi. Jika ada prosedur yang tidak dipenuhi dan prosedur yang tidak dipenuhi tersebut dapat dibuktikan, maka akta tersebut dengan proses pengadilan dapat dinyatakan sebagai akta yang mempunyai kekuatan pembuktian sebagai akta di bawah tangan. Jika sudah berkedudukan seperti itu, maka nilai pembuktiannya diserahkan kepada hakim. ${ }^{14}$

Jika pihak yang tersebut dalam akta merasa pihak yang menghadap kepada Notaris pada saat proses pembacaan dan penandatanganan akta tidak sesuai kenyataan seperti apa yang tertuang dalam salinan dan minuta akta tidak sesuai dengan kenyataan yang diyakininya benar, maka pihak yang bersangkutan melakukan pengingkaran terhadap kepastian hari, tanggal bulan, tahun, dan pukul menghadap yang tercantum dalam akta. Dalam kaitan ini diperlukan pembuktian dari pihak yang melakukan pengingkaran tersebut dan Notaris yang bersangkutan. Jika hal semacam itu dikategorikan sebagai suatu tindak pidana, maka Notaris dikualifikasikan melakukan tindak pidana Pasal 263, 264, 266, Jo 55 atau 56 KUHP.

Jika kita memahami apa yang tertuang dalam UUJN, dapat dipahami bahwa Notaris adalah suatu jabatan yang diawasi dengan sangat ketat. Pemerintah mengawasi pelaksanaan peraturan jabatan yang tertuang dalam UUJN dan juga kode etik Notaris melalui Majelis Pengawas Notaris di tingkat daerah, wilayah, maupun tingkat pusat. Dari internal organisasi jabatan Notaris sendiri, yakni Ikatan Notaris Indonesia (INI) memiliki Dewan Kehormatan untuk mengawasi dan memeriksa pelanggaran kode etik Notaris baik di tingkat daerah, wilayah, maupun tingkat pusat.

Pasal 1866 KUHPerdata menyebutkan bahwa bukti tulisan merupakan salah satu alat bukti tertulis. Demikian pula dalam Pasal 1867 KUHPerdata yang menyebutkan bahwa bukti tulisan merupakan salah satu alat bukti tertulis. Demikian pula dalam Pasal 1867 KUHPerdata yang menyebutkan bahwa pembuktian dengan tulisan dilakukan dengan tulisan-tulisan otentik maupun dengan tulisan-tulisan di bawah tangan. Kekuatatn pembuktian akta Notaris sebagai akta otentik mempunyai 3 macam nilai kekuatan pembuktian yaitu lahirian, formal, dan materiil.

Mengulas kekuatan pembuktian dari akta Notaris yang tidak dibacakan dan ditandatangani oleh penghadap secara bersama-sama, maka harus dipahami bahwa

${ }^{14}$ Habib Adjie, Penafsiran Tematik..., Op. Cit., hlm. 83-84. 
Notaris dalam menjalankan tugas dan jabatannya memformulasikan keinginan/tindakan para pihak ke dalam akta otentik, dengan memperhatikan aturan hukum yang berlaku. Akta Notaris sebagai akta otentik mempunyai kekuatan pembuktian yang sempurna, sehingga tidak perlu dibuktikan atau ditambah dengan alat bukti lainnya. Jika ada pihak yang menyatakan bahwa akta tersebut tidak benar atau tidak dilakukan dengan prosedur yang ada, dalam hal ini akta tidak dibacakan dan ditandatangani oleh Notaris secara bersama-sama dengan penghadap, maka pihak yang menyatakan tidak benar atau sebagai pihak yang dirugikan, wajib membuktikan pernyataannya sesuai dengan hukum yang berlaku.

\section{Penutup}

Dalam praktik pemberian kredit oleh lembaga perbankan kepada nasabah sudah lazim menggunakan jasa Notaris untuk mengikat para pihak dalam suatu akta perjanjian kredit yang dibuat oleh Notaris. Namun proses penandatanganan akta perjanjian kredit antara bank dan nasabahnya biasanya hanya dihadiri dan ditandatangani oleh nasabah, yang kemudian setelah akta tersebut ditandatangani oleh nasabah maka akta tersebut dikirim kepada pihak dari bank untuk selanjutnya ditandatangani oleh pihak dari bank. Hal yang demikian dianggap suatu hal yang biasa padahal apabila kita memperhatikan ketentuan atau prosedur-prosedur pembuatan akta otentik oleh Notaris maka hal yang demikian merupakan suatu pelanggaran aturan hukum yang sudah tentu berimplikasi hukum, baik terhadap akta itu sendiri maupun pihak-pihak yang tersebut di dalam akta itu. Kurangnya kesadaran Notaris dalam mengamalkan dan melaksanakan prosedur pembuatan akta otentik berdasarkan ketentuan undang-undang maupun lemahnya pengawasan dari lembaga-lembaga yang berkewajiban untuk mengawasi Notaris dalam menjalankan tugas dan jabatannya menjadikan hal ini terus menerus terjadi.

Pembacaan dan penandatanganan akta yang tidak dilakukan di hadapan Notaris akan berakibat turunnya nilai pembuktian akta otentik menjadi akta di bawah tangan sebagaimana tertuang dalam Pasal 16 ayat (9) UUJN dan melanggar ketentuan Pasal 4 ayat (6) Kode Etik Ikatan Notaris Indonesia yang menimbulkan konsekuensi yakni berupa sanksi yang dikenakan terhadap anggota (dalam hal ini Notaris) yang melakukan pelanggaran kode etik, yakni berupa teguran, peringatan; schorsing (pemecatan sementara) dari keanggotaan perkumpulan, onzetting (pemecatan) dari keanggotaan perkumpulan, pemberhentian dengan tidak hormat dari keanggotaan perkumpulan. 
Notaris yang menjadi rekanan bank harus sadar akan tugas dan kewenangannya serta jabatan yang diemban, sudah seharusnya Notaris menolak untuk mengikuti kehendak dari pihak bank yang meminta minuta akta yang telah dibacakan dan ditandatangani oleh Notaris dan nasabah untuk dikirim ke bank untuk selanjutnya ditandatangani sebab hal tersebut jelas bertentangan terhadap ketentuan UUJN dan kode etik Notaris yang akan berimplikasi hukum bagi Notaris itu sendiri di kemudian hari. Juga terhadap pihak bank dimana pihak dari bank tidak hadir pada saat proses peresmian akta (verlijden), dimana harusnya pihak bank harus konsisten dan patuh terhadap ketentuan pembacaan dan penandatanganan akta di hadapan Notaris bersama dengan nasabah sebab akta tersebut merupakan akta milik bank yang akan memberikan perlindungan dalam menjamin kepastian hukum jika debitor atau nasabah wanprestasi.

Kewajiban membacakan dan menandatangani akta di hadapan Notaris pada saat proses peresmian akta (verliejden acte)harus dipatuhi baik oleh Notaris maupun para pihak yang terkait, sebab apabila hal tersebut tidak terpenuhi dan dapat dibuktikan di pengadilan maka menimbulkan implikasi hukum terhadap akta tersebut yakni turun derajatnya menjadi akta di bawah tangan dan menimbulkan kerugian bagi para pihak sehingga para pihak mapun Notaris wajib untuk melaksanakan dan patuh terhadap ketentuan yang berlaku dalam proses peresmian akta. Juga perlunya peran aktif dari perkumpulan Notaris, yakni Ikatan Notaris Indonesia dalam bentuk koordinasi terhadap seluruh Notaris, khususnya Notaris yang menjadi rekanan bank agar benar-benar menjalankan tugasnya berdasarkan ketentuan perundang-undangan yang berlaku.

\section{Daftar Pustaka}

Buku

Adjie, Habib, Sanksi Perdata dan Administratif Terhadap Notaris Sebagai Pejabat Publik, Bandung, Refika Aditama, 2009.

Hukum Notaris Indonesia; Tafsir Tematik Terhadap Undang-Undang Nomor 30 Tahun 2004 Tentang Jabatan Notaris, Cetakan Keempat, Bandung: PT. Refika Aditama, 2014.

Anshori, Abdul Ghofur, Lembaga Kenotariatan Indonesia; Perspektif Hukum dan Etika, Cetakan Pertama, Yogyakarta, UII Press, 2009.

Bahsan, M., Hukum Jamninan dan Jaminan Kredit Perbankan Indonesia, Jakarta, PT. RajaGrafindo Persada, 2007.

Daurus, Muhammad Luthfan Hadi, Hukum Notariat dan Tanggung Jawab Jabatan Notaris, Cetakan Pertama, Yogyakarta, UII Press, 2017. 
Notosoedirjo, R. Soegondo, Hukum Notariat di Indonesia; Suatu Penjelasan, Jakarta, PT. RajaGrafindo Persada, 1993.

Sulihandari, Hartanti dan Nisya Rifiani, Prinsip-Prinsip Dasar Profesi Notaris, Jakarta, Dunia Cerdas, 2013.

Susanto, Herry, Peran Notaris Dalam Menciptakan Kepatutan Dalam Kontrak, Yogyakarta, UII Press, 2010.

\section{Peraturan Perundang-undangan}

Kitab Undang-Undang Hukum Perdata.

Undang-Undang Nomor 5 Tahun 1986 tentang Peradilan Tata Usaha Negara.

Undang-Undang Nomor 4 Tahun 1996 tentang Hak Tanggungan Atas Tanah Beserta Benda-Benda yang Berkaitan Dengan Tanah.

Undang-Undang Nomor 10 Tahun 1998 tentang Perbankan.

Undang-Undang Nomor 2 Tahun 2014 tentang Perubahan Atas Undang-Undang Nomor 30 Tahun 2004 tentang Jabatan Notaris.

Peraturan Pemerintah Republik Indonesia Nomor 24 Tahun 2016 tentang Perubahan Atas Peraturan Pemerintah Nomor 37 Tahun 1998 tentang Peraturan Jabatan Pejabat Pembuat Akta Tanah.

Permenkumham Nomor M.02.PR.08.10 Tahun 2004 tentang Tata Cara Pengangkatan Anggota, Pemberhentian Anggota Susunan Organisasi, Tata Cara Kerja dan Tata Cata Pemeriksaan Majelis Pengawas Notaris.

Keputusan Menteri Keuangan Republik Indonesia Nomor 338/KMK.01/2000 tentang Pejabat Lelang.

Kode Etik Notaris Ikatan Notaris Indonesia.

Anggaran Dasar Ikatan Notaris Indonesia (INI). 